\title{
US-Shrimp II (Vietnam): Dubious Application of Anti-Dumping Duties - Should Have Used Safeguards
}

\author{
BEN ZISSIMOS* \\ University of Exeter Business School \\ JAN WOUTERS** \\ Leuven Centre for Global Governance Studies, KU Leuven
}

\begin{abstract}
This article explores the idea that the USDOC imposed anti-dumping duties on Vietnamese shrimp producers despite the fact that the surge of shrimp imports giving rise to the duties may have come from elsewhere in the developing world. We argue that Vietnam's shrimp exporters may have been subject to antidumping duties because Vietnam has 'non-market economy' (NME) status in the United States. This makes it possible to levy higher duties against Vietnamese firms. We make the point that it was particularly inappropriate to impose antidumping duties against the Vietnamese shrimp industry because this industry shows clear indications of being perfectly competitive, whereby firms cannot dump. This in turn raises the question of how the USDOC was able to construct a dumping case where apparently none could have existed. Use of the 'zeroing' methodology, in conjunction with Vietnam's NME status, turns out to be central to the answer. The broader issue is that anti-dumping duties are overused where safeguards would be more efficient. The analysis is relevant for the current controversy over China's NME status with a number of its trading partners.
\end{abstract}

\section{Introduction}

For over a decade now, the United States Department of Commerce (USDOC) has been causing controversy with its approach to anti-dumping (AD) proceedings. This controversy has focused largely on the use of so-called 'zeroing' (Bown

\footnotetext{
*Email: B.Zissimos@exeter.ac.uk

**Email: jan.wouters@ggs.kuleuven.be

We thank Chad Bown and Petros Mavroidis for the opportunity to participate in the WTO Case Law Project. We are especially grateful to Chad Bown, Dominic Coppens, David DeRemer, Dylan Geraets, Jim Hartigan, Jennifer Hillman, Simon Lester, Tom Prusa, Julia Ya Qin, Maurizio Zanardi, and Isleide Zissimos for detailed comments and conversations about earlier drafts. We are also grateful for comments by participants at the conference on the Legal-Economic Analysis of WTO Case Law of 2015, at the European University Institute in June 2016. Finally, we would like to thank Isleide Zissimos for producing the figures in this article.
} 
and Sykes, 2008, Hoekman and Wauters, 2011, Prusa and Vermulst, 2011, Broude and Moore, 2013, Prusa and Roubini, 2013, Saggi and Wu, 2013, Ahn and Messerlin, 2014, and Hartigan, 2016). According to this practice, transactions with negative dumping margins are ignored in the determination of whether dumping has occurred and in the calculation of average dumping margins. This makes it more likely to find that dumping has occurred and it inflates the size of the average dumping margin calculated. Beginning with the US-Softwood Lumber $V^{1}$ complaint brought by Canada in 2002, numerous World Trade Organization (WTO) Appellate Body (AB) decisions have found the USDOC practice of zeroing to be impermissible under WTO rules. The USDOC has responded narrowly each time, eliminating the practice of zeroing in the specific factual context of the legal complaint but continuing the practice in other situations where the context differed very slightly. With so many AB decisions against it, hopes were raised that the USDOC would cease its practice of zeroing when it published its Final Modification for Reviews ${ }^{2}$ on 14 February 2012 which stated that it would do so. But the Panel Report on US-Shrimp II (Vietnam) (WTO, 2014) dashed these hopes when it found that the USDOC was back up to its old tricks.

The purpose of this article is to re-examine the Panel Report in US-Shrimp II (Vietnam), focusing on two of the Panel's key findings. The first is that, as already mentioned, the USDOC acted inconsistently with the WTO's AntiDumping Agreement (AD Agreement) by using a zeroing methodology. Second, the USDOC's presumption that all of Vietnam's shrimp producers/ exporters were part of a single non-market entity which received a single 'economy-wide rate' (EWR) was also found to be inconsistent with the AD agreement. This presumption was based in turn on the USDOC's designation of Vietnam as a non-market economy (NME). Based on these findings, we will explore the idea that there was an attempt to use $\mathrm{AD}$ measures in USShrimp II (Vietnam) where safeguards (SG) would have been more appropriate. ${ }^{3}$ Hartigan (2016) has undertaken a comprehensive analysis of the Panel Report US-Shrimp II (Vietnam) and suggested that perhaps the US should have used SG measures instead of imposing AD duties, but he did not explore this idea in detail. Building on Hartigan's work, our main argument that AD measures

1 United States - Final Dumping Determination on Softwood Lumber from Canada, DS264 (USSoftwood Lumber V).

277 Federal Register 8101.

3 We fully acknowledge that any case considered by a WTO Panel or the AB must examine the legality of the measures used in the case and cannot consider whether a different measure would have been more appropriate. Thus, our analysis is targeted at future complainants and those concerned with systemic issues of the world trading system. In this paper, we will not examine the fact that Vietnam appealed against one finding in the Panel Report. The reason is that the AB upheld the Panel's ruling and the appeal concerns the details of legal procedure, apparently not raising any economic issues. See US-Shrimp II (Vietnam) (WTO, 2015) for further details. 
were inappropriate in the case will hinge on the fact that, in order to dump, a firm must have the market power to set prices. Vietnamese firms, being small and numerous, clearly do not possess such power. We will argue instead that Vietnamese firms, being small, followed world prices downwards as the supply of shrimp onto the world market surged from elsewhere in the developing world. This is exactly the kind of shock that a SG action is intended to address. Our argument will also address the point that the USDOC was able to construct an AD case against firms in an industry that could not have been dumping. To do this, we will develop a simple economic model that will enable us to examine in detail both how dumping was demonstrated and how $\mathrm{AD}$ measures were applied in a perfectly competitive industry where in principle this should not have been possible. Using our framework, we will be able to see the sense in which AD and SG measures are substitutes. Moreover, we will be able to motivate the temptation to use $\mathrm{AD}$ duties where SG measures would have been more appropriate.

AD and SG measures are a form of temporary trade barrier (TTB), as are countervailing duties (CVDs). Why is the substitution of one type of TTB for another a cause for concern? Several distinctions have been identified in the prior literature between a SG policy on the one hand and AD or CVDs on the other. In the following, we will restrict attention only to $\mathrm{AD}$, partly because the concerns with CVDs apply in a similar way to $\mathrm{AD}$ duties and partly because, for a number of reasons, $\mathrm{AD}$ have traditionally been preferred over CVDs, certainly against countries having NME status. ${ }^{4}$ Arguably, the main distinction is that SG policies are seen both as 'fairer' and more efficient than $\mathrm{AD}$ duties. The reason is that the application of a SG policy is generally thought to result in MFN protection through non-discriminatory treatment of imports, irrespective of the source country. On the other hand, $\mathrm{AD}$ petitions apply new protection to imports from only one country per petition, thus allowing for differential and potentially discriminatory treatment across trading partners. The discrimination across export sources allowed for under AD would be more likely to result in trade diversion: to importers switching to product sources from higher cost (but non-targeted) foreign producers, thus inducing welfare losses to the domestic economy. The following factors are regarded to make the use of $\mathrm{AD}$ duties more attractive than $S G$ policies: the process of filing an $\mathrm{AD}$ petition is bureaucratic while Agreement on SG mandates a political process involving Presidential discretion; the injury threshold is higher

4 CVDs are imposed in order to counter foreign subsidies creating injury to the domestic industry. As Hartigan (2016) points out, a subsidy in a NME was traditionally not seen as countervailable by CVDs investigating authorities in the United States (and elsewhere), as there was no market to distort. He draws on Feldman and Burke (2013) who discuss the legal controversy created when the US court of International Trade and the US Court of Appeals for the Federal Circuit moved away from this approach and began to initiate AD and CVDs investigations simultaneously against China. 
for SG cases; the duration of SG is shorter than of $A D ;^{5}$ and the use of SG can require compensation to affected countries, while $\mathrm{AD}$ does not. ${ }^{6}$ In general, the fact that $\mathrm{AD}$ duties tend to be cheaper and more convenient to apply than a SG action serves to push countries towards the use of the less efficient $\mathrm{AD}$ approach (Bown, 2002). ${ }^{7}$

We argue that, going beyond the reasons set out above for using AD duties over a SG action, Vietnam's presumed NME status may have made it a more attractive target for the imposition of AD duties by the US. USGAO (2006), while focusing on China, show that all countries who have NME status attract 'inflated' dumping margins. The original investigation by the US International Trade Commission (USITC) named Brazil, China, Ecuador, India, Thailand, and Vietnam. In that investigation, the weighted average AD margin for mandatory respondents was calculated as $4.57 \%$ and maintained at that level throughout subsequent reviews. Contrast this with the significantly higher EWR applied to Vietnam of $25.6 \%$. Brink Lindsey of the Cato Institute has condemned the process for determining NME prices: 'Basically, you can come up with any dang number you want to' (Davis, 2012: 274). The Panel ruling on US-Shrimp II (Vietnam) set an important precedent in this regard. As mentioned above, it ruled that the USDOC's presumption that all of Vietnam's producers/exporters were part of a single non-market entity was found to be inconsistent with the AD agreement. This presumption would have been convenient because it would have made it relatively easy to apply the same 'inflated' EWR to over 300 Vietnamese shrimp processors. But according to the Panel, '[s]uch a practice runs directly counter to the obligation in Article 6.10 ... whereby an investigating authority "shall, as a rule, determine an individual margin of dumping for each known exporter or producer concerned"'. The precedent set by the Panel Report US-Shrimp II (Vietnam) should make it harder to apply a blanket EWR on countries with NME status in the future.

5 Prusa (2011) shows in particular that AD duties are applied to developing countries for longer than they are for developed countries, and this plays a role in the outcome that AD duties are applied for longer on average.

6 Sykes (2003) goes further in arguing that, because the first paragraph of GATT Article XIX was removed from the WTO's Agreement on Safeguards, the Agreement became inoperable. But Beshkar (2010) presents evidence that use of SG has gone up since the reform. Gnutzmann-Mkrtchyan and Lester (2016) argue similarly that the Agreement on SG functions reasonably well but that there is scope for reform.

7 But see Bown (2013), who identifies differential impacts across exporters to the US due to exceptions in the application of US steel SG policy. It is not clear how widespread these exceptions are. But it seems fair to argue that the application of SG is closer to being MFN than application of AD specifically because MFN is part of the design of SG whereas for AD it is not. One objection to the application of MFN across all exporters under a SG action is that the cost shocks giving rise to a surge in imports might be smaller in some exporting countries than others. But the Agreement on SG has a nullification and impairment provision to address such concerns. 
This ruling in US-Shrimp II (Vietnam), that a country cannot simply presume all firms in a NME are part of a single non-market entity, may have implications for China's NME status as well. The precedent set by the Panel Report US-Shrimp II (Vietnam) should make it harder to apply a blanket EWR on countries with NME status in the future. Under Section 15 of the WTO (2001) Chinese Accession Protocol, WTO Members may treat China as a NME in AD proceedings if Chinese firms cannot demonstrate that they operate under market economy conditions. However, Section 15 of the Chinese WTO Accession Protocol stipulates that this non-market presumption will expire 15 years after entry, that is, on 11 December 2016. China argues that this amounts to a guarantee of market status by that date. But this interpretation remains controversial. It rather seems to imply that importing countries will lose the right automatically to apply NME status for $\mathrm{AD}$ purposes. This dovetails with the ruling in US-Shrimp II (Vietnam) that it is not possible to presume that all firms in a NME are part of a non-market entity and so it is not possible to apply a single EWR. Because China's NME status will no longer be automatic after 11 December 2016, the decision over whether to grant China market economy status will become a geo-political one. It will incur costs in loss of political capital that must be balanced against the gains from greater protection from Chinese exports resulting from its NME status (Economist, 2016). The ruling in US-Shrimp II (Vietnam), by making it impossible to use NME status to apply a single inflated EWR to all firms, may help tip the balance for some trade partners in favor of granting China market economy status by 11 December 2016.

The article proceeds as follows. Section 2 first reviews how dumping works, emphasizing the point that dumping cannot be effective in a perfectly competitive industry. It then goes on to argue that the global shrimp industry is characterized by perfect competition, and that the Vietnamese industry in particular is perfectly competitive. Finally, this section reviews key findings of the case. It documents how the USDOC attempted to use the $\mathrm{AD}$ agreement to show that firms in the Vietnamese shrimp industry had been dumping and how the USDOC's approach was ultimately found to be inconsistent with the AD Agreement. Section 3 sets out our economic model of the effects of AD measures versus SG measures to examine how their incidence differs. The model provides further insight into how $\mathrm{AD}$ may be overused relative to SG measures. The section also explains the sense in which $\mathrm{AD}$ duties reduce efficiency relative to $\mathrm{SG}$ measures. Conclusions are drawn in Section 4.

\section{Background and summary of US-Shrimp II (Vietnam)}

\subsection{Dumping and market structure}

A key reason why we think that the use of $\mathrm{AD}$ measures seemed particularly inappropriate in the case is that the shrimp industry in Vietnam is perfectly 
competitive. This in itself raises doubt over whether Vietnamese firms could have been dumping. To see why, we will now provide a review of dumping and how it is affected by market structure (i.e. whether or not a market is imperfectly or perfectly competitive). Dumping is said to occur when a firm sets a lower price for its exports than it does in its home market or below its cost of production, generally referred to as selling below 'normal value'. The intention is generally to increase export market share. To be able to dump, the market in which a firm operates must be imperfectly competitive. A key feature of an imperfectly competitive market is that each firm has sufficient market power to set its own prices. That is, each firm must have sufficient capacity to drive down the prices of other firms in the market by increasing its own output.

By contrast, perfectly competitive firms are 'price takers' because their power in the market is so limited. In practical terms, their capacity is so limited that they cannot produce in sufficient quantities to drive prices down. The capacity of each firm is in turn limited by whether or not there is free entry. In markets that are perfectly competitive, there is nothing to stop new firms from entering the market and competing profits to zero. In that case, pricing below normal value would have a negligible effect on market prices while generating losses for the firm that did so. At the same time, any attempt to price above the normal value would be fruitless as well because consumers would purchase from other firms who were pricing at the normal value and making zero profits. This makes it impossible for any firm to recoup the losses incurred while dumping. Therefore, it does not make sense to think that firms operating in a perfectly competitive market structure could gain by attempting to dump. Thus, under perfect competition, free entry drives prices to the normal value.

\subsection{The Vietnamese shrimp industry in global terms: perfectly competitive}

We will now take a look at the data on the structure of the Vietnamese shrimp industry and how it sits in the world market for shrimp. Our main aim in doing this is to satisfy ourselves that the Vietnamese shrimp industry can reasonably be characterized by perfect competition.

In 2012, the export value of world trade in fish was US\$129.2 billion. The global shrimp industry was the largest single seafood industry in value terms that year, representing roughly $15 \%$ of the total value of internationally traded fishery products (FAO, 2014). Shrimp production is concentrated mainly in developing countries, and a large share of production is exported. China was the largest producer of shrimp in 2012, but was only the third largest exporter. Vietnam was the third largest producer behind China and Thailand, but the second largest exporter behind Thailand. The variation in rankings is accounted for by the fact that China consumes a relatively large share of its own production. Vietnam exported roughly US $\$ 2.5$ bn of shrimp in 2012. Most shrimp are exported to developed country markets, with the US (approx. \$5bn in 2012) and Japan (\$3bn) by far 
the largest single destinations. Over the 2000s, there has been sustained growth of shrimp farming, with global output of farmed shrimp reaching a record 3.4 million tonnes in 2012 (FAO, 2014). It is through farming that Asia has come to dominate the industry for shrimp, with producers of wild caught shrimp, especially in developed countries, squeezed by the lower cost Asian suppliers. Vietnam has been one of the countries whose industry has grown consistently through this period. But now their position among the top three exporting nations is being threatened by the growth of newer entrants, especially India whose shrimp output grew by $36 \%$ in 2012 (Holmyard, 2015). As we will explain in the next sub-section, we think that the significant growth in the output of shrimp from other countries such as India may have played a significant role in the USDOC's construction of the case that Vietnamese firms were dumping.

Turning to the Vietnamese fishing industry, according to the Vietnam General Office of Statistics (2006) there were 337,614 households in Vietnam engaged in shrimp farming, with each household being reasonably characterized as a small family firm (Lan, 2013). The Vietnamese firms that process and export the shrimp are somewhat larger and not as numerous at about 300. Nevertheless, shrimp processors and exporters are sufficiently numerous for this part of the industry to be characterized as perfectly competitive. On this basis, we think it is reasonable to characterize the Vietnamese shrimp industry as perfectly competitive as a whole. Unless it is important to make a distinction, Vietnamese shrimp producers and processors will henceforth be referred to collectively as 'Vietnamese firms'.

\subsection{Key aspects of the US-Shrimp II (Vietnam) case}

We begin with the background to the US-Shrimp II (Vietnam) case. As mentioned in the Introduction, the original investigation that gave rise to this case named Brazil, China, Ecuador, India, Thailand, and Vietnam as producers of the subject merchandise. It commenced on 31 December 2003, and the final report was issued in January of 2005 as USITC (2005). The investigation established a weighted average $\mathrm{AD}$ margin for mandatory respondents of $4.57 \%$ and an EWR applied to Vietnam of $25.6 \%$. This in turn gave rise to a prior dispute, USShrimp (Vietnam) (WTO, 2011). That dispute demonstrated: "that the wholesale use of "limited examination" under Article 6.10 ADA and the application of "all others" rates to a large number of exporting firms constituted a distortive practice, leaving much to the potentially unprincipled discretion of the [USDOC], and [left] many exporting firms with irrelevantly high dumping margins, and no recourse to administrative review' (Broude and Moore, 2013). Given the USDOC's narrow response, eliminating only the specific practices mentioned in the case, this prompted the subsequent dispute.

Here we go into more detail about the two key findings of the Panel Report on US-Shrimp II (Vietnam) (WTO, 2014). The first was that the USDOC acted 
inconsistently with the AD agreement by relying on WTO-inconsistent margins of dumping (based on zeroing) in its likelihood-of-dumping determination. The second concerned the presumption that Vietnamese firms were part of a single non-market entity. We will discuss each of these issues in greater detail. It is useful to review the first aspect here because this provides specific details of how dumping can be found even in a perfectly competitive industry where dumping should not be possible. It is useful to review the second aspect because it explains how AD duties could be applied to Vietnamese firms 'en masse', in much the same way as SG measures are applied. This fails to fulfil the obligation under the AD Agreement to determine an individual margin of dumping for each known exporter on a firm-by-firm basis.

We will now explain how the controversial practice of zeroing could have been used to find that Vietnamese firms were dumping in a perfectly competitive market structure. We will begin by focusing on how zeroing would lead to a finding of dumping in a global industry that is 'static' in the sense that average supply from all exporters is stable. We will then consider how the growth of exports from a third country such as India could have interacted with the practice of zeroing to increase the likelihood of finding that Vietnamese firms were dumping.

First the 'static' case. The purpose of an anti-dumping investigation is to establish whether or not a firm has been dumping. This investigation requires a comparison of how a firm sets its prices over time with the normal value of the good that the firm sells. The challenge with this type of investigation is that prices fluctuate over time for reasons beyond the control of the firm. Some of the many possible reasons that prices may fluctuate are that input prices and exchange rates fluctuate, demand conditions change, supply conditions such as weather may fluctuate, and so on. ${ }^{8}$ The controversy over the practice of zeroing concerns the action taken by investigators in instances where the export price is found to be higher than the normal value. One approach would be to treat such instances as 'negative dumping', which would be used to offset other periods of 'positive dumping' where the export price is found to be lower than the normal value. Another approach would simply be to set the value to zero in such instances. The latter approach is referred to as 'zeroing'. The practice of zeroing can significantly alter the outcome of a dumping investigation, both making it more likely that dumping will be found and increasing the calculation of the dumping margin. Consider a perfectly competitive industry, where competition drives all firms to price at the normal value on average. On this basis, it would be reasonable to use average prices to determine normal value at any given point in time. If all price observations were used to compute the average, and if this average were compared to normal

8 Hartigan (2016), drawing on previous research (Hartigan, 2000) explains how seasonality in agricultural and aquacultural industries provides another reason why prices will fluctuate above and below the normal value. 
value in order to calculate the dumping margin, then by construction average prices and the normal value would be equal and the dumping margin would be equal to zero as well. But if, as mandated by the zeroing methodology, all prices above average and hence above normal value were ignored, then a determination of dumping would be assured. Hence, a zeroing methodology would ensure a finding of dumping even in an industry that was perfectly competitive and pricing at normal value. The evidence considered by the Panel in US-Shrimp II (Vietnam) included the computer code used by the USDOC and this revealed that a zeroing methodology was indeed used, and was instrumental in the determination that Vietnamese firms had been dumping (WTO, 2014).

Now consider a situation where supply conditions are not static in the sense that a country other than Vietnam significantly increases its supply of shrimp to the world market. We are assuming that this increase in supply is caused by a 'cost shock' such as, for example, deregulation in India, which significantly reduces the price at which Indian firms can produce and export shrimp. This increase in supply will push the world price of shrimp downwards throughout the period of growth. Therefore, if as in the static case the average price is used to calculate normal value, the fact that the world price of shrimp is being pushed downwards on average makes it more likely than in the static case that at any given moment the world price of shrimp will be below average. It will also increase the margin by which the price will be found to be below average. This is the sense in which growth of exports from a third country such as India could have interacted with the practice of zeroing to increase the likelihood of finding that Vietnamese firms were dumping.

Regarding the second aspect of the case, Hartigan (2016) draws attention to the fact that the US conducts AD investigations in accordance with Title VII of the Tariff Act of 1930. This Act permits the characterization of economies as market economies or NMEs by US investigative authorities. As Hartigan (2016) emphasizes, this practice is not part of GATT VI or the AD Agreement. It is US practice. The prices in NMEs are deemed to be unreflective of scarcity and hence fair value. The USDOC's investigators are directed to utilize cost and price data from third countries in this instance. The USDOC begins with a rebuttable proposition that all firms in a NME will receive the same EWR. Firms may qualify for a separate rate $(S R)$ if they can establish to the satisfaction of the USDOC that they are sufficiently independent of the government in exporting. We have already mentioned in the Introduction the fact that this approach enabled the USDOC to effectively apply the same inflated EWR of $25.6 \%$ to a large number of the Vietnamese shrimp processors. Recall that it was the presumption of being able to apply a single EWR that the Panel found to be directly counter to the obligation in Article 6.10 to determine an individual margin of dumping for each known exporter or producer concerned. Here we also emphasize the fact that, by being able to apply the same AD duty to a large number of firms, this enabled the dumping measure to be applied to a first approximation like a tariff. A SG measure also essentially involves levying a 
tariff. This means that in our model, presented in the next section, we can compare directly the application of an $\mathrm{AD}$ duty with the application of an equivalent SG policy in terms of the imposition of a tariff.

\section{A model of anti-dumping versus safeguard measures}

Since the situation we are focusing on relates to trade for shrimp between the US and Vietnam, the economic model we develop focuses on these two countries. We will adapt a textbook international economics model (Krugman et al:: 2015: chapter 9) to the present context. Our model focuses on the US as the importer of shrimp and Vietnam as the exporter. Focusing on the US as the only importer of shrimp is not a bad first approximation since it is by far the largest importer of shrimp in the world. Although our model focuses on Vietnam as an exporter of shrimp, the twist we introduce allows for the possibility that other countries export shrimp to the US as well. The production of shrimp will be characterized in our model by perfect competition. Based on the evidence we have provided above, this is also not a bad approximation to the real world.

\subsection{The basic model}

The basic model is illustrated in Figure 1. Panel A of Figure 1 shows the market for Vietnamese shrimp in the US; panel B shows Vietnamese shrimp available for export to the US; panel C illustrates the interaction between these two markets to determine US-Vietnamese shrimp trade and the world price of shrimp. We will describe panel B first since that is standard. The twist we introduce to the model is shown in panel A so we will consider that next. Then we will consider the interaction of these two markets in panel C. Continuing first to outline the general features of the model, a fall in the market price for shrimp leads consumers in both the US and Vietnamese markets to demand more shrimp. In this sense, shrimp are regarded as a normal good. This is reflected in downward-sloping demand curves in panels A and B. Also, a rise in the price of shrimp leads more producers to enter the market and the supply of shrimp to increase. Nevertheless, even as the price of shrimp increases, each individual firm makes normal/zero profits as a result of free entry. This is reflected in upward-sloping supply curves in panels A and $\mathrm{B}$.

Panel B shows the domestic demand curve and domestic supply curve for shrimp in Vietnam. The horizontal axis shows quantities demanded and supplied while the vertical axis shows the price of shrimp in Vietnam. The autarky price in Vietnam, $p^{V}$, arises where the Vietnamese demand and supply curves intersect. At this price, all domestic demand is satisfied by domestic supply and so there is no trade. For any price above $p^{V}$, Vietnamese supply of shrimp is greater than demand. The so-called 'excess supply' of shrimp is equal to the quantity that Vietnam exports. Since we have assumed that the US is the only market for shrimp, in our model Vietnam 
Figure 1. US-Vietnam shrimp trade baseline

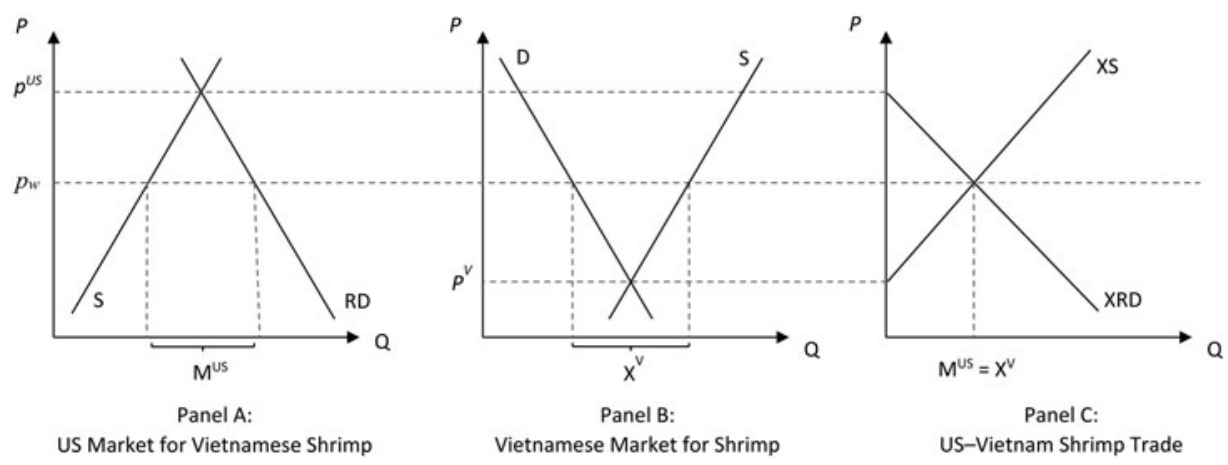

only exports shrimp to the US. The diagram shows a world price, $p_{w}$, that lies above $p^{V}$, at which Vietnam exports shrimp to the US.

Panel A illustrates the same picture of the market for shrimp as panel B but in the US this time. There are two crucial differences between the two panels. First, in panel A the supply curve is shifted to the left, indicating that at any given price the US supplies less shrimp than Vietnam. Thus, panels A and B taken together indicate that Vietnam has a comparative advantage in shrimp, which is the basis on which Vietnam will tend to export shrimp to the US. The second difference is that the downward sloping curve in panel $\mathrm{A}$ is not the domestic demand curve as in panel B but the so-called 'residual demand curve' for Vietnamese shrimp by the US. That is, it is the US demand for Vietnamese shrimp taking as given imports of shrimp from all other shrimp-exporting countries. Accordingly, the curve is labelled RD for 'residual demand' instead of just D. Therefore, $p^{U S}$ is not the autarky price from the US perspective but the price at which the US would cease trading with Vietnam. For any price below $p^{U S}$, the US has 'excess residual demand' for shrimp and this is satisfied by imports from Vietnam. As we will see, the advantage of focusing on the RD curve instead of the regular (domestic) demand curve is that it enables us to take account of surges in the supply of shrimp from other markets on US-Vietnamese trade and the world price.

Panel C shows the Vietnamese excess supply (XS) curve and the US excess residual demand (XRD) curve. The XS curve represents the quantity exported by Vietnam to the US at any given world price. The XRD curve represents the quantity imported by the US from Vietnam at any given world price. We will now explain how the XS supply curve works by looking at the specific features of this curve. The intercept of the XS curve in panel C is at Vietnam's autarky price level, $p^{V}$, determined in panel B. At price $p^{V}$, Vietnamese excess supply and hence exports would be zero as shown in panel B. For any world price $p_{w}$ above $p^{V}$, the horizontal difference between the vertical axis of panel $\mathrm{C}$ and the XS curve is equal to the horizontal difference between the demand and supply curves in panel B. Thus, for any 
given value of $p_{w}$, the quantity of exports can be determined either from panel B or from panel C. Similarly, the intercept of the XRD curve is at $p^{U S}$, indicating that US excess residual demand and hence imports from Vietnam would be zero at this price level, as shown in panel A. For any world price $p_{w}$ below $p^{U S}$, the horizontal difference between the vertical axis of panel $\mathrm{C}$ and the XRD curve is equal to the horizontal difference between the RD curve and supply curve in panel A.

Let us now consider how the model can be used to determine world prices, $p_{w}$. The simplest approach is to take as given (i.e. fixed) shrimp exports by the rest of the world to the US. The idea might be that the rest of the world is already at full capacity and so cannot expand further. Then the world market for shrimp clears when, in panel $\mathrm{C}, p_{w}$ adjusts to the level where XS is equal to XRD. The world price $p_{w}$ shown in panel $C$ lies above $p^{V}$ and below $p^{U S}$, and so represents a price level at which Vietnam will export shrimp to the US. In addition, at $p_{w}$, the quantity, Q, or 'volume' of trade between the US and Vietnam is the same whether we see this from the perspective of Vietnamese exports to the US, $\mathrm{X}^{\mathrm{V}}$, or US imports from Vietnam $\mathrm{M}^{\mathrm{US}}: \mathrm{M}^{\mathrm{US}}=\mathrm{X}^{\mathrm{V}}$. This is the sense that the world market is said to 'clear' at $p_{w}$. This provides a useful illustration of how the market for Vietnamese shrimp exports to the US operates in isolation.

A more complex but realistic approach, which takes account of how trade varies with $p_{w}$ between all shrimp exporters and the US, involves replacing the assumption that we take as given shrimp exports by the rest of the world to the US. Assume instead that, for a given world price $p_{w}$, each country's export share of the US market for shrimp is fixed. This assumption allows variation in population, technologies, and transport costs across countries to translate into different trade shares across countries. Vietnam may export more shrimp to the US than India partly because it has 'the right' climatic and geographical conditions, and partly because it has a relatively large labor force whose wages are relatively low. Taking trade shares as given, we then say that a fall in $p_{w}$ will decrease exports of shrimp by all countries to the US in a way that preserves these trade shares. So total exports of shrimp to the US decrease with a fall in $p_{w}$ but trade shares do not change. Under this approach, we could draw a diagram like the one in Figure 1 for each country that exports to the US. Now assume that we start at a world price level that is 'too high' in the sense that there is excess supply of shrimp from all exporting countries to the US. With excess supply, $p_{w}$ will fall and the quantity of shrimp exported by all countries to the US will fall simultaneously in such a way that the export market share of each country remains fixed. This leads towards a situation where the markets of all countries clear in that $p_{w}$ equates XS and XRD for all countries simultaneously.

What if we reach a level of $p_{w}$ where the markets for one or more countries clear but others do not? To see how we reach a situation where all markets clear, first consider the simplest possible situation where all markets but one clear. For concreteness, say that the markets for shrimp in all countries except Vietnam clear at $p_{w}$. Say that while $p_{w}$ clears all other markets, this value of $p_{w}$ is 'too high' to 
clear the market in Vietnam: In Figure $1, p_{w}$ would be at a level where XS is greater than XRD. Because at this level of $p_{w}$ there is excess supply of shrimp from Vietnam to the US, the price of shrimp from Vietnam must fall relative to shrimp elsewhere in the world. The resulting increase in the competitiveness of Vietnamese shrimp is captured by an increase in US residual demand for shrimp from Vietnam. Therefore, the imbalance is corrected partly by a shift to the right of the RD curve in panel A and the XRD curve in panel C. At the same time, this process is mirrored by shifts to the left of the RD curves and XRD curves for all the other countries in a way that preserves their export shares to the US relative to each other. But these shifts will allow Vietnam's share of the export market to the US to increase at the expense of the other countries. The overall effect would be a fall in $p_{w}$ at the same time as an increase in relative demand for Vietnamese shrimp. This rebalancing would continue until the world market clears for Vietnam at the same value for $p_{w}$ as for all other countries. Having seen how this process of rebalancing would work for a single country, we can now imagine how it would work for any and all countries. Through this process, a value of $p_{w}$ is attained that clears the world market (that is, the sum of trade in all markets) for shrimp.

\subsection{Dumping, or a negative residual demand shock?}

We can now use the model developed above to consider the implications of a surge in exports to the US from a country or a number of countries other than Vietnam. Assume that initially we are at a value of $p_{w}$ that clears world markets. For simplicity, let us associate the surge with a single country, India, corresponding to the surge in exports from India to the US documented in Section 2.2 above. (But keep in mind that the surge is not necessarily restricted to just one country.) The shrimp industry in India may have enjoyed some form of deregulation or technological innovation that enabled the price of shrimp supplied by India to fall relative to the prices of all the other shrimp exporting countries. This would be captured by a shift to the right of the supply curve and XS curve for India, and an increase in India's exports of shrimp at any given value of $p_{w}$. To understand the effect of this export surge from India, we can apply the analysis we discussed in Section 3.1. Now India is in the same position as we described for Vietnam in Section 3.1. That is, $p_{w}$ clears the market for all countries except India, while for India there is excess supply of shrimp from India to the US. Following exactly the same line of argument as in Section 3.1, we see that $p_{w}$ falls, while this time it is India's RD and XRD curves that shift to the right and those of all other countries including Vietnam that shift to the left. The leftward shift of the RD and XRD curves for Vietnam is illustrated in Figure 2 as a shift to $\mathrm{RD}^{\prime}$ in panel A and $\mathrm{XRD}^{\prime}$ in panel $\mathrm{C}$ respectively. The new curves are shown as dashed.

The fall of $p_{w}$, illustrated in Figure 2 as a fall to $p_{w}{ }^{\prime}$, corresponds to the fall in the world price of shrimp resulting from an export surge from India that we discussed 
Figure 2. US-Vietnam shrimp trade after relative demand shock

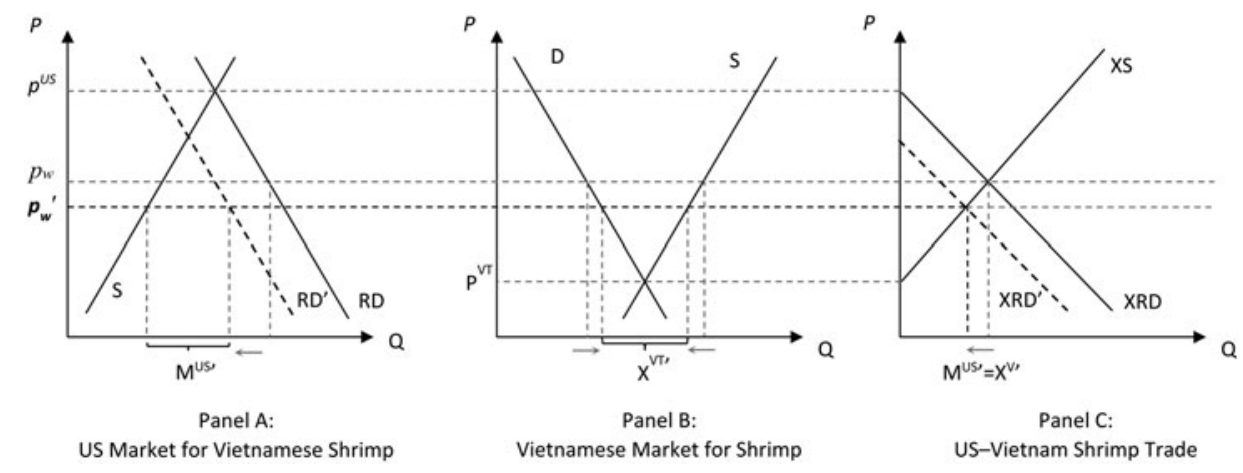

in Section 2.2. In that discussion we noted that, under a zeroing methodology, this fall in world prices to $p_{w}{ }^{\prime}$ would increase the likelihood of finding that Vietnamese firms were dumping. In the case of dumping, prices fall because Vietnamese firms have the market power to set lower prices themselves. But in the case of a negative residual demand shock in a competitive market, Vietnamese firms are, by taking prices, following the world price of shrimp downwards. This type of shock is exactly the type of shock that SG measures were originally intended to address.

How can we tell whether the driving force behind the fall in prices is dumping or a residual demand shock? If dumping alone were the driving force behind the fall in prices charged by Vietnamese firms, then we would expect the fall in prices to be accompanied by an increase in the volume of trade between the US and Vietnam. After all, the purpose of dumping would be to increase Vietnamese firms' share of the US market. By contrast, as can be seen from panels A, B, and C of Figure 2, the result of a negative residual demand shock is a reduction in the volume of US-Vietnamese trade in shrimp to $\mathrm{M}^{\mathrm{US}^{\prime}}=\mathrm{X}^{\mathrm{V}^{\prime}}$. This is shown in panel $\mathrm{A}$ as a reduction in US imports, and in panel $\mathrm{B}$ as a reduction of Vietnamese exports, while panel $\mathrm{C}$ shows the conjunction of the two. This feature of the outcome provides a useful 'prediction' that could be taken from the data to confirm whether a negative residual demand shock, and not dumping, lay at the heart of the fall in prices charged by Vietnamese firms.

\subsection{What is the difference between AD measures and SG measures?}

Let us assume that there has been a negative shock to US residual demand for Vietnamese shrimp of the kind illustrated in Figure 2. We will now compare the alternative responses to this shock by the US using $\mathrm{AD}$ duties on the one hand or a SG policy on the other. Recall our discussion of Section 2.3 where we noted that, under the circumstances of the US-Shrimp II (Vietnam) case, AD duties and a SG policy can be regarded as substitute policies since both may be applied in the manner of a tariff. 
In order to undertake a direct comparison between $\mathrm{AD}$ duties and a SG policy, we will assume that each is applied at the same rate as the other. This assumption is not realistic when one considers that the political economy process involved in the application of $\mathrm{AD}$ duties and a SG policy are significantly different. Most importantly, application of AD duties requires a sympathetic USDOC, whereas a SG policy involves support of the President. So given the decision to seek protection via one or other of these policies, the actual rate that results from the political economy process may vary across the two. For the purposes of the present comparison between $\mathrm{AD}$ and $\mathrm{SG}$, we will set these issues aside in order to understand the variation in the incidence of a given rate across the two types of measure. Also for the sake of making a direct comparison, in the first instance we will assume that the trade policy is applied only to Vietnam. This too is simplifying because, especially with a SG policy, there is an allowance for MFN application across a number of countries. There is also the possibility to apply AD duties across a number of countries without the MFN provision, as discussed in the Introduction. We will leave these issues aside for now but return to them in due course. In Figure 3 the trade measure is applied at $t$, whether it is an AD duty or a SG measure.

We must make one further assumption about the rate at which $t$ is applied. We will assume that the intention of the trade measure from the perspective of US firms is to restore the domestic price level and the level of aggregate output to their levels before the negative residual demand shock. This too is a strong assumption. Once efforts are undertaken to seek protection, there may be an attempt by the industry in question to obtain better terms than it had before. Or there may be a response by interest groups who purchase the product. In the instance of shrimp, this could be the domestic catering and hospitality industry, who offset protectionist impulses from those competing with imports. In this regard, our assumption that $t$ restores the domestic price level and domestic output to the levels prior to the residual demand shock represents a benchmark.

The original domestic price level, prior to the negative residual demand shock, is given in Figure 1 as equal to the original world price level, $p_{w}$. This price level is reproduced in Figure 3 at $p_{w}$. If, after the negative residual demand shock, the trade policy $t$ restores the domestic price level to its original level at $p_{w}$, then the level of supply by the US shrimp industry will be restored to its original level as well. Note that the application of $t$ will serve to reduce the demand by US consumers for shrimp from Vietnam, and with it the world price of shrimp. From Figure 3, we can see that if the tariff level $t$ restores the domestic price to $p_{w}$, then the world price will be reduced to $p_{w}{ }^{\prime \prime}$. Figure 3 also shows that the volume of trade is reduced further still under the trade measure, to $\mathrm{M}^{\mathrm{US}}=\mathrm{X}^{\mathrm{V}^{\prime \prime}}$.

Under the assumptions we have made so far, where a SG measure is applied only to Vietnamese firms, its effect on the world price and volume of trade would be the same as $\mathrm{AD}$ duties applied through a single EWR at the same rate. However, there is a crucial difference between the incidences of the policies, which adversely affect 
Figure 3. US-Vietnam shrimp trade with RD shock and AD measures

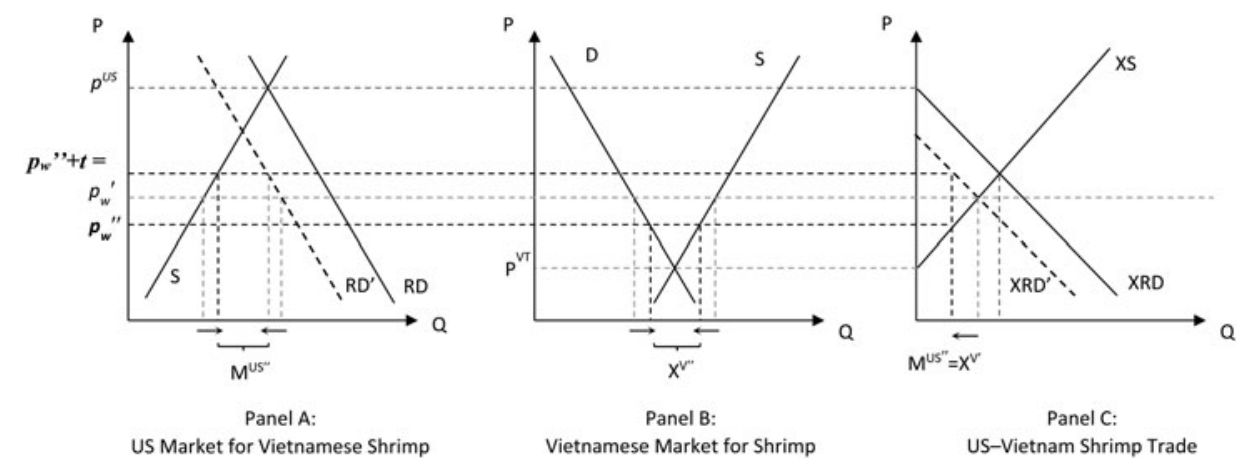

Vietnamese firms under the AD measure relative to the SG measure. Because the SG measure works in the same way as a regular tariff, US consumers pay the duty of the SG policy. This duty is calculated as the tariff multiplied by the volume of trade: $t . \mathrm{M}^{\mathrm{US}}$. This contrasts with the $\mathrm{AD}$ measure, where the total amount of revenue raised is the same but it is Vietnamese firms that pay the duty.

Let us now relax the assumption that we made previously that the alternatives of an AD measure or a SG measure would necessarily be applied at the same rate, $t$, to Vietnam. In the Introduction, we discussed the point that application of a single EWR in a NME has given rise to inflated dumping margins. This approach is not available under a SG measure and suggests margins may have been higher under the AD measure actually adopted than if a SG policy had been used. The availability of a nullification and impairment provision under the Agreement on SG but not AD is likely to have contributed further to a differential involving higher duties under AD than SG. The fact that AD duties can be applied for longer than SG is also a consideration because, as explained above, these measures were initially applied in 2005 and would normally have been removed after three years under a SG policy. All of these factors tend to favor the application of AD over SG by the US.

What about the fact that SG policies would have been applied by the US to all exporters on an MFN basis whereas the AD duty in question here was applied on shrimp from Vietnam at a significantly higher EWR? Spreading the load of this policy more evenly across countries with a SG policy would surely have benefitted Vietnam in this instance. It would also have led to a more efficient outcome for the US since Vietnam is a relatively efficient producer of shrimp and the AD duties would have caused consumers to switch to less efficient suppliers. ${ }^{9}$

9 An understanding of how AD duties may reduce efficiency can be gleaned from Figure 3. Say that AD duty is applied only to Vietnamese firms. Then the price US consumers pay for Vietnamese shrimp is $p_{w}=$ 
Application of a SG policy on an MFN basis might itself be distortionary if, say, India was the only country from which the surge in exports originated. But the nullification and impairment provision in the Agreement on SG could have been used to address that concern.

\section{Conclusions}

This article has re-examined the case of US-Shrimp II (Vietnam) focusing on the Panel's two key findings: that the USDOC acted inconsistently with the AD agreement by using a zeroing methodology; the USDOC's presumption that all of Vietnam's producers/exporters were part of a single non-market entity which received a single EWR was also found to be inconsistent with the AD agreement. Based on these findings, we explored the idea that there was an attempt to use $\mathrm{AD}$ measures where SG would have been more appropriate. Our main argument that $\mathrm{AD}$ measures were inappropriate was based on the fact that, in order to dump, a firm must have the market power to set prices. We presented evidence that Vietnamese firms are in fact too small and numerous to have the market power to dump. We presented a new theoretical framework to show how Vietnamese firms, being small, followed world prices downwards as the supply of shrimp onto the world market surged from elsewhere in the developing world. This, we argued, is exactly the kind of shock that a SG action is intended to address. Our framework focused on the comparable effects of an AD duty or SG policy applied only to Vietnam at the same rate $t$. But from there we argued that $\mathrm{AD}$ duties were likely to have been applied at a higher rate on Vietnam than would have been possible under a SG policy and for longer, arguably undermining overall economic efficiency in the process.

What are the implications for future disputes of the key findings of WTO (2014) Panel Report US-Shrimp II (Vietnam)? The finding that both the zeroing methodology and the application of a single EWR were found to be inconsistent with the AD Agreement suggests that it will be more difficult to adopt the same approach to the application of $\mathrm{AD}$ duties in future. At the margin, one has to think that this may make use of the more efficient Agreement on SG more likely in the future. Perhaps the biggest effect will be indirect, through the influence of this ruling on

$p_{w}{ }^{\prime \prime}+t$ while the price that Vietnamese firms charge is only $p_{w}{ }^{\prime \prime}$. So the cost to the US of importing shrimp from Vietnam is $p_{w}{ }^{\prime \prime}$. The prices charged for shrimp by firms in other countries less efficient than Vietnam will be greater than $p_{w}$ " but if firms in those countries are not targeted by AD duties then their prices to US consumers may be less than $p_{w}{ }^{\prime \prime}+t$. If so, US consumers will tend to switch to their exports of shrimp instead. The fact that the US could have imported the shrimp from Vietnam at the lower price of $p_{w}{ }^{\prime \prime}$ represents an efficiency loss to the US. This effect is known as 'trade diversion'. US shrimp producers gain because they benefit from the protection. But the harm done to US consumers and the US economy as a whole can be shown to be greater than the benefit to US shrimp producers. Note that trade diversion does not happen under SG because it is applied on an MFN basis, that is, at the same rate across all exporting countries. 
the approach to $\mathrm{AD}$ cases against China. At the time of writing, no country is accused of dumping as often as China. For example, it is currently the target of 28 out of 38 anti-dumping investigations by the European Commission. If Panel Report US-Shrimp II (Vietnam) makes it less attractive to target China, as a NME, with AD duties, then we may see a shift at the margin towards SG on that basis alone. This would bring about a welcome improvement in the efficiency and perceived fairness of the world trading system. But a more cynical view might be that, especially given the current US bipartisan consensus of being tough in enforcing trade agreements with China, the USDOC may find a way around the rulings of US-Shrimp II (Vietnam) as well. ${ }^{10}$

The new theoretical framework introduced in this article offers two main directions for future research. One is theoretical, involving a full formal development of the theoretical model. For reasons of tractability, much of the literature on the application of $\mathrm{AD}$ versus $\mathrm{SG}$ has been based around two-country models. (Crowley, 2006 and Hartigan, 2015 are notable exceptions.) A limitation of a two-country model is that it misses the trade diversion effects we discussed in this article, whereby applying $\mathrm{AD}$ duties at too high a rate on Vietnam would cause a switch to less efficient suppliers. The model developed in the present article offers a simple framework through which this type of effect could be taken into account. This framework could also form the basis of a model that could be used for structural estimation, making it possible to obtain quantitative measures of the efficiency effects we have been discussing.

\section{References}

Ahn, D. and P. Messerlin (2014), 'United States-Anti-Dumping Measures on Certain Shrimp and Diamond Sawblades from China: Never Ending Zeroing in the WTO?', World Trade Review, 13(2): 267-279.

Beshkar, M. (2010), 'Trade Skirmishes Safeguards: A Theory of the WTO Dispute Settlement Process', Journal of International Economics, 82: 35-48.

Bown, C. P. (2002), 'Why are Safeguards under the WTO So Unpopular?', World Trade Review, 1: 47-62.

— (2013), 'How Different Are Safeguards from Antidumping? Evidence from US Trade Policies Toward Steel', Review of Industrial Organization, 42: 449-481.

Bown, C. P. and A. O. Sykes (2008), 'The Zeroing Issue: A Critical Analysis of Softwood V', World Trade Review, 7(1): 121-142.

Broude, T. and M. Moore (2013), 'US - Anti-Dumping Measures on Certain Shrimp from Viet Nam: A Stir-Fry of Seafood, Statistics and Lacunae', World Trade Review, 12(2): 433-462.

Crowley, M. A. (2006), 'Do Safeguard Tariffs and Antidumping Duties Open or Close Technology Gaps?', Journal of International Economics, 68: 469-484.

10 It may be argued that that USDOC has already done so. This is the so-called 'targeted dumping' approach in the second sentence of Article 2.4.2 of the ADA, and which has recently been subject to two challenges in the WTO: United States - Anti-dumping and Countervailing Measures on Large Residential Washers from Korea, DS464; United States - Certain Methodologies and their Application to Anti-Dumping Proceedings Involving China, DS471. 
Davis, C. L. (2012), Why Adjudicate? Enforcing Trade Rules in the WTO, Princeton, NJ: Princeton University Press.

Economist, The (2016), 'The 15-Year Hitch: A Pact from 2001 Stirs Trouble between China and the West, and between America and Europe', 7 May 2016.

Feldman, E. J. and J. J. Burke (2013), 'Testing the Limits of Trade Law Rationality: The GPX Case and Subsidies in Non-Market Economies', American University Law Review, 62(4): 787-825.

Food and Agriculture Organization (FAO) (2014), The State of World Fisheries and Aquaculture: Opportunities and Challenges, Rome: United Nations Food and Agriculture Organization.

Gnutzmann-Mkrtchyan, A. and S. Lester (2016), 'Does Safeguards Need Saving? Lessons from the Ukraine-Passenger Cars Dispute', Leibnitz University and Cato Institute.

Hartigan, J. (2000), 'Is the GATT/WTO Biased Against Agricultural Products in Unfair International Trade Investigations?', Review of International Economics, 8(4): 634-646.

_ (2015), 'Did the Agreement on Safeguards Nullify their Use?', Global Economy Journal, 15(1): 155172

_ (2016), 'It's Baaaack - Zeroing, the US Department of Commerce, and US-Shrimp II (Viet Nam)', World Trade Review, 15(2): 287-302.

Hoekman, B. and J. Wauters (2011), 'US Compliance with WTO Rulings in Anti-Dumping', World Trade Review, 10(1): 5-43.

Holmyard, N. (2015), 'Is Vietnam's Shrimp Industry in Crisis?', Sea Food Source, 30 December, http:// www.seafoodsource.com/all-commentary/is-vietnam-s-shrimp-industry-in-crisis.

Krugman, P. R., M. Obstfeld, and M. J. Melitz (2015), International Economics: Theory and Policy, 10th edn, Harlow: Pearson Education Ltd.

Lan, N. T. P. (2013), 'Social and Ecological Challenges of Market-Oriented Shrimp Farming in Vietnam', Springerplus, 2: 675.

Prusa, T. (2011), 'USA: Evolving Trends in Temporary Trade Barriers', in C. Bown (ed.), The Great Recession and Import Protection: The Role of Temporary Trade Barriers, London and Washington, DC: CEPR and The World Bank.

Prusa, T. J. and L. Roubini (2013), 'United States - Use of Zeroing in Anti-Dumping Measures Involving Products from Korea: It's Déjà Vu All over Again', World Trade Review, 12(2): 409-425.

Prusa, T. J. and E. Vermulst (2011), 'United States - Continued Existence and Application of Zeroing Methodology: The End of Zeroing?', World Trade Review, 10(1): 45-61.

Saggi, K. and M. Wu (2013), 'Yet Another Nail in the Coffin of Zeroing: United States - Anti-Dumping Administrative Reviews and Other Measures Related to Imports of Certain Orange Juice from Brazil', World Trade Review, 12(2): 377-408.

Sykes, A. O. (2003), 'The Safeguards Mess: A Critique of WTO Jurisprudence', World Trade Review, 2(3): 261-295. (Reprinted in The WTO, Safeguards, and Temporary Protection from Imports, Chad P. Bown (ed.), Cheltenham, UK: Edward Elgar, 2006.)

US Government Accountability Office (USGAO) (2006), 'US-China Trade: Eliminating Nonmarket Economy Methodology Would Lower Antidumping Duties for Some Chinese Companies', Report to Congressional Committees GAO-06-231, US Government Accountability Office.

US International Trade Commission (USITC) (2005), 'Certain Frozen or Canned Warmwater Shrimp and Prawns from Brazil, China, Ecuador, India, Thailand, and Vietnam', US International Trade Commission Publication 3748, January 2005.

Vietnam General Office of Statistics (2006), Rural and Agricultural Fishery Census, Hanoi: Vietnam General Office of Statistics.

WorldTradeLaw.net (2015), Dispute Settlement Commentary, United States-Anti-Dumping Measures on Certain Shrimp from Viet Nam, WT/DS429/R, last update 29 August 2015.

World Trade Organization (WTO) (2001), 'Report of the Working Party on the Accession of China', WT/ $\operatorname{MIN}(01) / 3$.

_ (2014), Panel Report, United States - Anti-Dumping Measures on Certain Shrimp from Viet Nam, WT/DS429/R, circulated 17 November 2014.

- (2015), Appellate Body Report, United States - Anti-Dumping Measures on Certain Shrimp from Viet Nam, WT/DS429/AB/R, adopted 22 April 2015. 